\title{
Ergo-effects of designed school furniture and sitting positions on students' behaviour and musculo-skeletal disorder in Nigerian tertiary institutions
}

\author{
A. I Musa ${ }^{a^{*}}$, S. O. Ismaila ${ }^{b^{*}}$, S. B. Adejuyigbe ${ }^{b}$ and O.D. Akinyemi ${ }^{c}$
}

${ }^{a}$ Mechanical Engineering Department, Moshood Abiola Polytechnic, P.M.B. 2210, Abeokuta, Nigeria

${ }^{b}$ Mechanical Engineering Department, University of Agriculture, P.M.B. 2240, Abeokuta, Nigeria

${ }^{c}$ Physics Department, University of Agriculture, P.M.B. 2240, Abeokuta, Nigeria

\begin{tabular}{|c|c|}
\hline A R T I C L E I N F O & A B S T R A C T \\
\hline $\begin{array}{l}\text { Article history: } \\
\text { Received October } 252010 \\
\text { Received in revised form } \\
\text { 01 February } 2011 \\
\text { Accepted 02 March } 2011 \\
\text { Available online } \\
\text { 07 March 2011 } \\
\text { Keywords: } \\
\text { MSD } \\
\text { Furniture } \\
\text { Student } \\
\text { School }\end{array}$ & $\begin{array}{l}\text { Improper design of school furniture is one of the contributing factors to back pain among } \\
\text { students as indicated in some studies. In the case of designing school furniture where sitting } \\
\text { constitutes a considerable time in the school, seat becomes important for comfort. This study is } \\
\text { carried out in three selected institutions in Nigeria to determine level of musculoskeletal } \\
\text { disorder in students' and the furniture that they use. } 720 \text { questionnaires with } 240 \text { students ( } 120 \\
\text { boys and } 120 \text { girls) drawn from each participating institutions were administered and } 675 \\
\text { responses were received. The results show that the number of students having MSD, accounted } \\
\text { for } 93.75 \% \text {. However, the distributions of pain in the body parts in each school were different. } \\
\text { The musculoskeletal pain, mostly concentrated on neck, right shoulders right elbow right wrist } \\
\text { right hand, upper back and lower back. The result also reveals that most of the students are } \\
\text { sitting on chairs with seat that are too high and too deep or too shallow and of tables that are too } \\
\text { high. However, it is recommended that further study on effect of designed school furniture and } \\
\text { sitting position in larger sample of students' representative in Nigeria tertiary institutions should } \\
\text { be carried out in order to reduce the effect of body pains. }\end{array}$ \\
\hline
\end{tabular}

(c) 2011 Growing Science Ltd. All rights reserved.

\section{Introduction}

There is little consensus on whether comfort and discomfort should be regarded as a bipolar continuum or as composing two experimental dimensions. Hertzberg (1968) first operationally defined comfort as "the absence of discomfort". Richardson (2005) later suggested that the fact that people do rate their subjective responses across the entire continuum indicate that positive comfort is part of a bipolar dimension that can be attributed to characteristics of design. The desirable worksurface height for writing differs from the optimum typing work-surface height; the desirable seatback angle frequently differs if the works is engaged in writing. Visual discomfort and muscular discomfort particularly in the neck and shoulders are occupational health concerns for people who work with computer (Bergqvist \& Knave, 1994; Bergqvist et al., 1995).

\footnotetext{
* Corresponding author. Tel: +(234) 8035050573

E-mail addresses: kunlemusa@yahoo.com (A. I.Musa) 
In terms of ergonomics, comfort integrates a sense of well-being with health and safety. Conversely, discomfort could be related to biomechanical factors involving muscular and skeletal system (Zhang et al., 1996). The comfort, physical health, well-being and performance of people can be increased by designing equipments, furniture and other devices according to the needs of the human body. One of the conditions to support productivity is to ensure that work spaces and equipment that people use conform to the anthropometric and biomechanical characteristics of the users (Metin et al., 2008). The discomforts of muscle contracture of neck and back problems are due to sitting for a long time at inappropriate posture, resulting from bad habits or by using furniture that is not consistent with anthropometric characteristics of the users (Zhang et al., 1996).

Various studies have shown that ill fitted designs in classroom furniture have contributed to high incidence of musculoskeletal disorders among school students (Olsen et al, 1992). Mismatch between school furniture and anthropometric measurement of students is a causative factor for low back pain and musculoskeletal discomfort in school students (Diep, 2003; Legg et al., 2003; Molenbroek et al., 2003). Furthermore, musculoskeletal stress resulting from efforts to maintain stability and comfort in sitting is not conducive for learning. Preventing these ill-effects of improper school furniture should be a health concern for everyone. Inadequate school furniture is frequently taken to be the reason for severe posture problems in adulthood. Therefore, furniture used by students for considerable periods of time need to be evaluated carefully (Schroder, 1997).

Prolonged sitting with poor posture is associated with the development of lower back pain (Jenny et al., 2001). Nowadays, lower back pain (LBP) in school students is a serious public health problem (Olsen et al., 1992). School-based surveys have shown a high prevalence of backache and particularly LBP among students. The reported cumulative prevalence varies from country to country, Finland, 20\% (Salminen.1984), England, 27\% (Fairbank et al., 1984); Canada, 33\% (Mierau et al., 1989); USA, 36\% (Olsen et al., 1992); France, 51\% (Troussier et al., 1994). The author is not aware of any reported data for Nigeria. The first pain episodes often occur at 13 to 14years of age and the prevalence increase with age (Troussier et al., 1994). Among school children aged 8 to 12years, the cumulative prevalence of LBP is lower, 6\% was reported by Troussier et al., (1994) and 11.6\% was reported by Burton et al. (1996). Approximately, 23\% of elementary school children complain of backache and that percentage rises to about 33\% among the secondary school population (Mierau. 1989). Linton et al. (1994) tested the effects of implementing ergonomically designed school furniture on measures of comfort, sitting posture and symptoms in three classes of fourth grades (10years old) in comparison with control group using traditional furniture. They found that the experimental class rated their furniture as being significantly more comfortable and experienced a reduction in musculoskeletal symptoms relative to the control group after implementing the ergonomically designed furniture. The result suggests that furniture design is one aspect of a multidimensional problem. This study is an attempt to estimate and determine the level of musculoskeletal disorder and opinion of students about fitness of the furniture in three randomly selected tertiary institutions in Abeokuta, Nigeria.

\section{Methodology}

\subsection{Sample Selection}

Three tertiary institutions in Abeokuta, Ogun State, south-west Nigeria were selected to participate in the research. The institutions are University of Agriculture (UNAAB), Moshood Abiola Polytechnic (MAPOLY) and Federal College of Education (FCE). 720 questionnaires with 240 students (120 boys and 120 girls) drawn from each participating institutions in respect to musculoskeletal disorder and opinion of students about fitness of the furniture were administered and 675 responses were received.

\section{Results and discussion}

Many students complained musculoskeletal pains. The results show that the number of students having musculoskeletal disorder, MSD, accounted for 93.75\% (Table 1). However, the distribution of pains in the body parts in each school was different. FCE had the highest number of students having or complaining of MSD with 93.8\% of the 225 students that responded. In MAPOLY, 95.0\% of 
students complained of one or the other MSD out of the 228 respondents and UNAAB had $92.5 \%$ out of 222 respondents (Table 1 ).

Table 1

Number of students having Musculoskeletal Disorder in each School

\begin{tabular}{|c|c|c|c|c|c|c|c|c|c|c|c|c|c|}
\hline & Having MSD & \multicolumn{3}{|c|}{ Neck Shoulder } & \multicolumn{2}{|c|}{ Elbow } & \multicolumn{2}{|c|}{ Wrists } & \multicolumn{2}{|c|}{ Hand } & \multirow[b]{2}{*}{ Uppe } & & \\
\hline & No & $\%$ & $\mathrm{~L}$ & $\mathrm{R}$ & $\mathrm{L}$ & $\mathrm{R}$ & $\mathrm{L}$ & $\mathrm{R}$ & $\mathrm{L}$ & $\mathrm{R}$ & & ickLower & BackKnees \\
\hline FCE $(n=240)$ & 225 & 93.845 & 4 & 17 & 9 & 14 & 1 & 24 & 2 & 26 & 35 & 48 & Nil \\
\hline MAPOLY $(n=240)$ & )228 & 95.055 & Nil & 12 & 15 & 30 & Nil & 20 & Nil & 29 & 32 & 20 & 15 \\
\hline UNAAB $(n=240)$ & 222 & 92.535 & 5 & 13 & 3 & 5 & Nil & 39 & Nil & 33 & 42 & 47 & Nil \\
\hline Total $(\mathrm{n}=720)$ & 675 & 93.8135 & 9 & 42 & 27 & 49 & 1 & 83 & 2 & 88 & 109 & 115 & 15 \\
\hline
\end{tabular}

The musculoskeletal pain, mostly concentrated on neck, right shoulders right elbow right wrist right hand, upper back and lower back. Some studies found the relationship between back, neck pain with mismatch of furniture. Mandal (1982) in his research found that $60 \%$ of students complained of pains in back, neck or shoulder for which they blamed the furniture. Salminen et al. (1992) also thought that low back pain was at least to some extent due to an unsuitable school table. The relationship between mismatch and musculoskeletal pains was found in the study. Evan et al. (1992) found that a mismatch between thigh length and seat depth was significantly related to general seat discomfort and that a mismatch in the seated elbow height and the table height was significantly related to pain in the shoulders and neck. However, the failure of anthropometric mismatch to fully account for expressed pain suggests that other factors contributing to postural discomfort need to be sought (Evan et al., 1992)

Table 2

Students Opinion about Fitness of Furniture (Tables and Chairs) in the Selected Schools

\begin{tabular}{|c|c|c|c|c|c|c|c|c|c|c|c|c|c|c|c|c|c|c|}
\hline \multicolumn{8}{|c|}{ TABLES } & \multicolumn{11}{|c|}{ CHAIRS } \\
\hline & \multirow[b]{2}{*}{$\mathrm{SEX}(\mathrm{M} / \mathrm{F})$} & Too high & High & \multicolumn{2}{|c|}{ Fits } & \multicolumn{2}{|c|}{ Low } & \multicolumn{2}{|c|}{ Too low } & \multicolumn{3}{|c|}{ Too high } & \multirow{2}{*}{$\begin{array}{c}\text { High } \\
\%\end{array}$} & \multirow{2}{*}{\multicolumn{2}{|c|}{ Fits }} & \multicolumn{2}{|c|}{ Low } & Too low \\
\hline & & $\mathrm{N} \%$ & $\mathrm{~N} \%$ & $\mathrm{~N}$ & $\%$ & $\mathrm{~N}$ & & $\mathrm{~N}$ & $\%$ & $\mathrm{~N}$ & $\%$ & $\mathrm{~N}$ & & & & $\mathrm{~N}$ & $\%$ & $\%$ \\
\hline \multirow[t]{2}{*}{ FCE } & & 4036.1 & 2522.5 & 29 & & 1311 & & 4 & 3.6 & 39 & & & 28.8 & 5 & 22.5 & 12 & & 2.7 \\
\hline & & 3530.7 & 521.9 & 25 & & 2320 & & 6 & 5.4 & 42 & 36 & & 23.7 & 3 & & 23 & 20.29 & 7.9 \\
\hline \multirow[t]{2}{*}{ MAPOLY } & & 5044.6 & 2421.4 & 10 & 8.9 & 108. & & 18 & 16.1 & 47 & 42.0 & & 21.4 & 0 & 17.9 & 8 & 7.113 & 11.6 \\
\hline & & 5749.1 & 2017.2 & 12 & & $151 ?$ & & 12 & 10.3 & 45 & 30.0 & & 18.1 & 10 & 155 & 17 & 14.715 & 12.9 \\
\hline \multirow[t]{2}{*}{ UNAAB } & & 25 & 4037.7 & 23 & & & & 3 & & 32 & & & 38.7 & 5 & 14.2 & 15 & 23 & 2.8 \\
\hline & $=116)$ & 3229.1 & $45 \quad 40.9$ & 22 & 20.0 & 1311 & 1.8 & 4 & 3.6 & 30 & 25.9 & 43 & 37.1 & 18 & 15.1 & 15 & 12.910 & 8.62 \\
\hline
\end{tabular}

Table 2 showed the number and percentage of students in the selected schools whose body dimensions fit the table height among the table - chair combination. The data in this tables shows that for most of the students, table-chair combination available in the classroom yield table height that exceed acceptable functional elbow heights. Most of the chairs tended to be too high for most of the students and were also too deep and shallow for many students. Only about $22.5 \%$ male, $11.4 \%$ female of FCE claimed that the chairs were adequate while $77.5 \%$ male and $88.6 \%$ female complained of either the chairs were too high, high, low or too low. Similarly, $85.8 \%$, 83.0\% male and $84.9 \%, 84.5 \%$ female students of UNAAB and MAPOLY respectively complained of misfit.

The data reveals that most of the students are sitting on chairs with seat that are too high and too deep or too shallow and of tables that are too high. Though, the student's body dimensions are dependent on age and gender. There was only one size of table and chair in each classroom showed variability among students at the same institutions. Even after controlling for body stature (height), female are less likely to find fitting chairs. Similarly, Evan et al., (1992), studied on 224 students in four schools and evaluated the fitness between school tables, chairs and students body sizes. The mismatch was found between thigh length and seat depth and between the seated elbow height and the table height (Evan et al., 1992).

\section{Conclusion and recommendation}

The present study may be a pointer to the effect in the design of furniture for use in tertiary institutions with the effect of musculoskeletal disorder and the sitting position of the Nigerian 
students considered. The present study showed that the furniture's in the classrooms were designed without consideration for the anthropometric measurements of Nigerian students. Most students are sitting on chairs with seats that are too low, too high and too deep or too shallow also the table clearance is too low. The effect of mismatches between school furniture and body dimensions are yet to be touch in Nigerian tertiary institution students which suggest a study on its impact so that proper governmental regulation can be set up in Nigeria to develop the new dimensions of ergonomic school furniture for students and equally develop guideline for schools for optimising the match between schools furniture and students body size. Further study on effect of designed school furniture and sitting position with consideration to the mismatch between students body size in larger sample of students representative in Nigeria tertiary institutions should be carried out in order to develop the new dimensions of ergonomic school furniture for students and reduced the effect of body pains.

\section{References}

Bergqvist, U., Wolgast, E., Nilsson, B., \& Voss, M., (1995). Musculoskeletal disorders among visual display terminal workers: individual, ergonomic, and work organizational factors. Ergonomics 38, 763-776.

Bergqvist, U.O., \& Knave, B.G., (1994). Eye discomfort and work with visual display terminals. Scandinavian Journal of Work Environment Health 20, 27-33.

Burton, A.K., Clark, R.D., McClune, T.D., \& Tillotson, K.M., (1996). The natural history of low back pain in adolescents. Spine 201, 2323-2328.

Diep N.B., (2003). Evaluation of fitness between school furniture and children body size in haiphong, Vietnam [dissertation]. Vietnam: Lulea Institute of Technology.

Evans, O., Collins, B. \& Stewart, A., (1992). Is school furniture responsible for student seating discomfort?. Proceedings of the 28th Annual Conference of the Ergonomics Society of Australia, Melbourne.

Fairbank J.C.T., Pynsent, P.B., Van Poortvliet, J.A \& Phillips, H., (1984). Influence of anthropometric factors and joint laxity in the incidence of adolescent back pain. spine, 9, 461-464.

Hertzberg, H.T.E. (1968). The Conference on Standardization of Anthropometric Techniques and Terminology. American Journal of Physical Anthropology, 28, 1-15.

Legg, S J., Pajo, K., Sullman, M \& Marfell-Jones, M., (2003). Mismatch between classroom furniture dimensions and student anthropometric characteristics in three New Zealand secondary schools. Proceedings of the $15^{\text {th }}$ Congress of the International Ergonomics Association, Ergonomics for Children in Educational Environments Symposium, 6, 395-7, Seoul, Korea, 24-29 August.

Linton, S. J., Hellsing, A. L., Halme, T., \& Akerstedt, K. (1994). The effects of ergonomically designed school furniture on pupils' attitudes, symptoms and behaviour. Applied Ergonomics, 25, 2399-2304.

Mandal, A.C., (1982). The correct height of school furniture. Human Factors, 24, 257-269.

Mierau, D., Cassidy, J.D., \& Young-Hing, H., (1989). Low back pain and straight leg raising in children and adolescents. Spine, 14, 526-528.

Molenbroek J.F.N., Kroon-Ramaekers \& Snijders C. J. (2003). Revision of the design of a standard for the dimensions of school furniture. Ergonomics, 46(7), 681 - 694.

Olsen, T. L, Anderson, R.L, Dearwater, S.R., Kriska, A.M., Cauley, J.A., Aaron, D.J, \& Laporte R.E., (1992). The epidemiology of low back pain in an adolescent population. American Journal of Public health, 82(4), 606-608.

Pynt, J., Higgs, J., \& Mackey, M. (2001), Seeking the optimal posture of the seated lumbar spine. Physiotherapy theory and practice, 17, 1, 5-21.

Richardson, A. (2005). A brief guide to design education. http://www.core77.com/design.edu/readme.asp.

Salminen J., (1984). The adolescent back. Acta Pediatrican Scandinavica, 315, 1-12.

Salminen, J. J., Pentti, J. \& Terho, P. (1992). Low back pain and disability in 14 years old school children. Acta Paediatrica Scandinavica, 81,1034-1039.

Schroder, I., (1997). Variation of sitting posture and physical activity in different types of school furniture. Coll Anthrop, 21(2), 397-403.

Troussier, B., Davione, P., de Gaudemaries, R., R., Fauconnier, J, \& Phelip, X., (1994). Back pain in school children; A case study among 1178 pupils. Scandinavian Journal of Rehabilitation Medical, 26(3), 143146.

Tunay, M. \& Melemez, K. (2008). Analysis of Biomechanical and Anthropometric parameters on Classroom furniture design. African Journal of Biotechnology, 7 (8).

Zhang, L., Helander, M.G., \& Drury, C.G. (1996). Indentifying factors of comfort and discomfort in sitting. Human Factors, 38 (3), 377-389. 